\title{
Mario Einaudi and Francois Goguel:
}

\section{Christian Democracy in Italy and France}

An analysis of the achievements, organizations and problems of the Christian Democratic Parties in Italy and France.

$\$ 4.00$

\section{Waldemar Gurian:}

\section{Bolshevism, an Introduction to Soviet Communism}

"It is excellent and certainly fills a great need. It should be widely read and used." Clyde Kluckhohn, Director of the Russian Research Center, Harvard University.

THE UNIVERSITY OF NOTRE DAME PRESS

NOTRE DAME, INDIANA

\section{International Shipping Cartels BY DANIEL MARX, JR.}

Subtitled $A$ Study of Self-Regulation by Shipping Conferences, this book takes up such ramifications as: tramp rationalization schemes, nonconference liner competition, deferred rebates, and the use or abuse of monopoly power which these devices involve.

The author was a shipping company executive for a number of years before coming to Dartmouth, where he is now professor of economics.

READY IN FEBRUARY

$\$ 6.00$ at your bookstore or from

PRINCETON UNIVERSITY PRESS

Princeton, New Jersey 


\section{FREE INDIA IN ASIA}

\section{By WERNER LEVI}

This carefully documented study surveys India's position in the whole of Asia and her relations with each of the countries in the area, with emphasis on developments since India's independence in 1947. Much of the material is based on Dr. Levi's personal observations and interviews with India's leaders during a recent visit to the country.

Phillips Talbot of the American Universities Field Staff says: "I applaud the publication of this book, both for its interpretation, which I regard as basically sound, and because it will evoke a discussion that may help to clear the air."

Dr. Levi, professor of political science, University of Minnesota, is the author of Fundamentals of World Organization and American-Australian Relations.

$$
\text { †⿰冫 University of Minnesota Press, Minneapolis }
$$

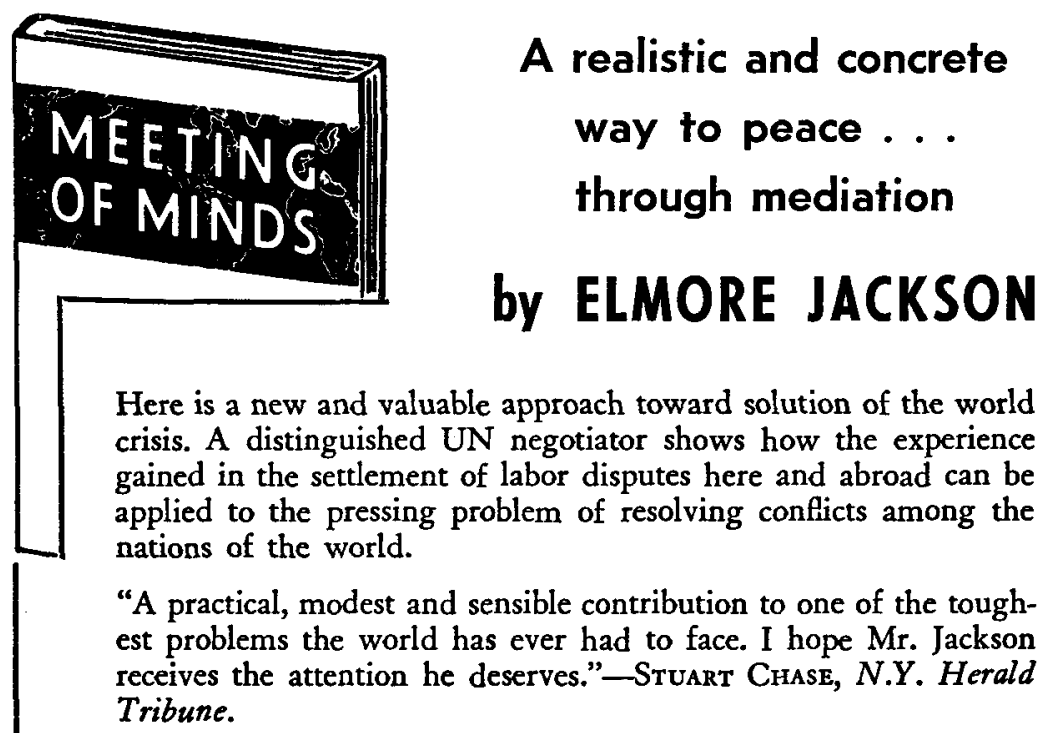

$\$ 3.50$ at all bookstores

McGRAW-HILL BOOK Co., New York 36 